УДК 619:616.36/.61:591.478.1:636.8, DOI 10.31210/visnyk2018.02.20

(C) 2018

Тимошенко О. П., доктор біологічних наук,

Снопенко О.C., аспірант

(науковий керівник - доктор біологічних наук, професор О. П. Тимоченко)

Харківська державна зооветеринарна академія

\title{
ЗМІНА ПЛОЩІ ВОЛОСЯНОЇ КУТИКУЛИ У СВІЙСЬКИХ КОТІВ ЗА НЕФРОПАТІЇ ТА ПОЛІОРГАННОЇ ПАТОЛОГІї
}

\section{Рецензент - доктор ветеринарних наук, професор І. В. Яценко}

Встановлено, щуо за різних варіантів нефропатії та за розвитку печінково-ниркового $i$ нирковопечінкового синдромів у свійських котів у печінці й нирках відбуваються значні структурні зміни, яким відповідають порушення метаболічних прочесів, визначених за результатами клініко-мікроскопічних та біохімічних досліджень крові, а також у змінах площчі волосяної кутикули (ПВК) шерстного покрову свійських котів. Методику визначення ПВК можна використовувати в диференційній діагностиці різних варіантів патології нирок $і$ печінки в комплексі з клінічними, інструментальними та лабораторними дослідженнями, а також за диспансерного обстеження тварин даного виду. У статті наведено приклади різних варіантів патологї̈ із визначенням ПВК.

Ключові слова: коти, нефропатія, поліорганна патологія, площуа волосяної кутикули, діагностика.

Постановка проблеми. Захворювання нирок у свійських котів складають значну частину внутрішньої незаразної патології тварин цього виду $[1,2,10,11]$. Досить часто на тлі різних варіантів нефропатії розвивається поліорганна патологія у формі нирково-печінкового та печінковониркового синдромів $[3,12,15]$, які важно диференціювати за результатами тільки клінічних та рутинних лабораторних досліджень. У ветеринарній медицині загальний шкірний покрив тварин вважається важливим органом-індикатором, досліджуючи який можна розпізнати прояви різних органічних захворювань (за структурними змінами шкіри і волосяного покриву). Вони є дзеркалом, що відображає стан організму $[4,7,8]$.

Склад волосся суттєво змінюється за різних патологічних станів, відповідає на дію несприятливих умов і стресових факторів, а токсиканти i важкі метали накопичуються у волоссі в кількостях, що значно перевищують їх концентрацію у крові. Волосся відображає довготривалі зрушення обміну речовин, а його склад віддзеркалює стан організму в порівняно тривалі відрізки часу $[4,7]$. Виходячи 3 цього, дослідження показників стану волосяного покриву свійських котів за різ- них варіантів нефропатії та поліорганної патології печінки й нирок здається актуальним і доцільним у плані диференційної діагностики та встановлення маловідомих ланок патогенезу захворювань цих систем.

Аналіз основних досліджень і публікацій, у яких започатковано розв'язання проблеми. Специфіка будови та властивостей волосся разом із доступністю його дослідження викликає інтерес різних груп вчених. Вивчення волосся як об'єкта біологічних, медичних та криміналістичних експертиз $\epsilon$ порівняно новим видом досліджень [5, 9], зокрема у ветеринарії $[4,9]$. Розробка та удосконалення досить простих і легких у виконанні методів дослідження волосся 3 використанням малих об'ємів матеріалу, зокрема площі волосяної кутикули (ПВК), є актуальними для діагностики внутрішніх незаразних хвороб тварин, оскільки вони до сих часів майже не виконувались. Нами раніше були опубліковані дані обстеження групи свійських котів за гепатопатії 3 печінково-нирковим синдромом. Було встановлено, що активність АлАТ і АсАТ як показник значного цитолізу гепатоцитів збільшувалась у 6,0 та 8,0 разів, а вміст сечовини і креатиніну - у 5,0 і 2,4 рази відповідно, що свідчить про розвиток за обох синдромів хронічної ниркової недостатності (XНH) четвертого і третього ступеня тяжкості за системою IRIS [13, 14]. Монопатологія печінки в котів у залежності від форми і стадіï захворювання супроводжувалась змінами ПВК у діапазоні від 7 Ч $10^{-4}$ до $15410^{-4} \mathrm{Hм}^{2}$. За печінково-ниркового синдрому у $90 \%$ хворих котів ПВК коливалась у межах 6Ч $10^{-4}-10410^{-4} \mathrm{Hм}^{2}$. Взагалі, за захворювань печінки не зустрічались значення ПВК $16410^{-4} \mathrm{Hм}^{2}$ і вище [13]. Результати аналогічних досліджень щодо розмірів ПВК за нефропатії не проводились.

Мета і завдання дослідження. Мета дослідження - встановлення закономірностей змін площі волосяної кутикули в домашніх котів за ниркової недостатності, а також поліорганної нирково-печінкової патології. 


\section{ВЕТЕРИНАРНА МЕДИЦИНА}

Основним завданням було вивчення можливості диференціювання ниркової моно- і поліорганної нирково-печінкової патології за значеннями ПВК.

Матеріали і методи. Дослідження проводили на базі клінік ветеринарної медицини м. Харків і кафедри клінічної діагностики та клінічної біохіміі ХДЗВА. Було досліджено 89 самиць і самців свійських котів, у віці 2,5-10,0 років (у 76 особин відбирали зразки шерсті), з яких у 69 тварин були встановлені клінічні симптоми захворювань нирок або поліорганної нирковопечінкової патології. Також було обстежено 20 клінічно здорових свійських котів різних порід i статі у віці від 6 місяців до 18 років. Хворих тварин досліджували загально-клінічними та спеціальними методами (гематологічні, гістологічні дослідження, УЗД, визначення ПВК). Матеріал був оброблений за допомогою математичних методів.

Об'єктом дослідження для обчислення ПВК слугувало остьове волосся свійських котів. Пучки шерстного покрову відрізалися продезінфікованими ножицями в середній частині правого боку, якомога ближче до шкіри. 3 метою видалення сторонніх домішок і забруднень волосся мили в теплій воді з 2,0 \% розчином господарського мила. Додатково волосся промивали спиртом 3 наступним випаровуванням. Промиті зразки послідовно тричі обробляли дистильованою водою і піддавали знежиренню сумішшю діетилового ефіру і етанолу (1:1). Підготовка зразків проводилася за методикою Н. А. Діомидової, О. П. Панфілова та Є. К. Сусліна [5]. Вивчення кутикули проводили за допомогою негативних відбитків на нітроцелулозному лаку, який наносили на предметне скло, щільно притискаючи до нього зразок. Після застигання лаку волосся знімали 3 предметного скла 3 периферийного кінця. Отриманий відбиток вивчали під мікроскопом Carl Zeiss Jena (зб.Ч400) і обчислювали ПВК у кореневій зоні і в найбільш товстій частині стрижня, виражаючи результат у нм² [5].

Результати досліджень. Згідно 3 нашими попередніми результатами, за ХНН рівень сечовини в сироватці крові свійських котів у середньому був вище у 6, а концентрація креатиніну - у 3,5 рази відносно значень контрольної групи. За ГНН вміст сечовини зростав у меншому ступені - у 3,5 рази, а креатиніну - в середньому у 2,0 рази, що свідчило про менший ступінь ушкодження нефронів за ГНН. Активність АлАТ і АсАТ за ХНН збільшилась у 2,0 рази, за ГНН - у 1,6 та 2,0 рази відповідно. Отже, значення цих показників відрізнялись від вищенаведених результатів за гепатопатії $[13,14]$.

За нирково-печінкового синдрому, тобто за первинного ураження нирок, активність обох амінотрансфераз зростала лише у 2,0 рази, проте вміст сечовини і креатиніну було збільшено у 6,0 та 4,0 рази, у той час як за первинного ураження печінки - у 5,0 та 2,4 рази.

Отже, за отриманими результатами ми диференціювали синдроми внутрішньої поліорганної патології домашніх котів у залежності від первинної ланки ушкодження (печінки або нирок).

На підставі результатів, отриманих за проведення загально-клінічних і лабораторних досліджень, нами були сформовані групи хворих котів, що стали основою для вивчення динаміки площі клітин волосяний кутикули (ПВК) шерстного покрову в цих тварин (табл. 1,2 ).

У таблиці 1 наведено розміри площі волосяний кутикули (ПВК) у зростаючому порядку від 6 до 17410-4 нм$^{2}$. Далі, у вертикально розташованих стовпчиках зазначено кількість тварин, в яких були підраховані ПВК, і відсотковий вміст даного показника в кожній групі відносно загальної кількості тварин. Аналіз результатів показав, що зниження ПВК супроводжує розвиток патологічного процесу.

Виявилось, що у здорових котів (група 1) стовідсотково були відсутні значення ПВК у діапазоні 6-7Ч10-4 HмI; величина ПВК 8-9Ч10-4 $\mathrm{HмI}$ виявилась у $40 \%$ випадків; більша ж частина тварин (60 \%) мала ПВК від 10-17Ч10-4 нмІ (табл. 2). Таким чином, чим більше ПВК, тим менше ймовірність, що у тварини є прихована форма захворювання нирок або поліорганна патологія. ПВК $15 Ч 10^{-4} \mathrm{HмI}$ і вище практично повністю виключає таку можливість, аналогічно як і відсутність ПВК в діапазоні 6-7Ч10 ${ }^{-4}$ нмІ. Ці показники, з нашої точки зору, дозволять диференціювати здорових тварин у 100 \% випадків від котів із прихованими, початковими формами патології, яку ми вивчали.

За нашими даними, за патології нирок (група 2) тварини $з$ показниками ПВК 6-7Ч10-4 нмІ зустрічаються найбільш часто (у 55,6 \% випадків). У міру того як площа волосяної кутикули збільшувалась, кількість тварин із патологією нирок знизилась. За значення ПВК 8-9410-4 нмІ частота фіксування хворих на патологію нирок котів склала 22,2 \%. 3 показниками ПВК $11410^{-4}$ та $12410^{-4} \mathrm{Hм}^{2}$ не було жодної хворої тварини. Таким чином, величини ПВК за хвороб нирок у $88,8 \%$ хворих свійських котів коливаються в межах від 6Ч10-4 до $10410^{-4} \mathrm{Hм}^{2}$. 
ВЕТЕРИНАРНА МЕДИЦИНА

1. Площа волосяної кутикули (ПВК) у свійських котів

\begin{tabular}{|c|c|c|c|c|c|c|c|c|c|c|}
\hline ПВК, нм & 1 & $\%$ & 2 & $\%$ & 3 & $\%$ & 4 & $\%$ & 5 & $\%$ \\
\hline $6 Ч 10^{-4}$ & - & - & 3 & 16,7 & 3 & 15 & 1 & 7,15 & 4 & 11,77 \\
\hline $7 Ч 10^{-4}$ & - & - & 7 & 38,9 & 6 & 30 & 2 & 14,29 & 8 & 23,5 \\
\hline $8 Ч 10^{-4}$ & 4 & 20 & 2 & 11,1 & 4 & 20 & 2 & 14,29 & 6 & 17,65 \\
\hline $9 Ч 10^{-4}$ & 4 & 20 & 2 & 11,1 & 2 & 10 & 4 & 28,57 & 6 & 17,65 \\
\hline $10 Ч 10^{-4}$ & 5 & 25 & 2 & 11,1 & 3 & 15 & 3 & 21,4 & 6 & 17,65 \\
\hline $11410^{-4}$ & 2 & 10 & - & - & 1 & 5 & 1 & 7,15 & 2 & 5,89 \\
\hline $12 Ч 10^{-4}$ & 2 & 10 & - & - & 1 & 5 & 1 & 7,15 & 2 & 5,89 \\
\hline $13 Ч 10^{-4}$ & - & - & 1 & 5,6 & - & - & - & - & - & - \\
\hline $14 Ч 10^{-4}$ & 2 & 10 & 1 & 5,6 & - & - & - & - & - & - \\
\hline $15 Ч 10^{-4}$ & - & - & - & - & - & - & - & - & - & - \\
\hline $16 Ч 10^{-4}$ & - & - & - & - & - & - & - & - & - & - \\
\hline $17 Ч 10^{-4}$ & 1 & 5 & - & - & - & - & - & - & - & - \\
\hline Усього & 20 & 100 & 18 & 100 & 20 & 100 & 14 & 100 & 34 & 100 \\
\hline
\end{tabular}

1 - клінічно здорові свійські коти, $n, \%$;

2 - коти с патологією нирок, $n$, \%;

3 - коти з печінково-нирковим синдромом, $n$, \%;

4 - коти з нирково-печінковим синдромом, $n$, \%;

5 - коти з поліорганною патологією (обидва синдроми разом), $n$, \%.

2. ПВК у котів залежно від діапазону значень (відсоткове співвідночення)

\begin{tabular}{|c|c|c|c|c|}
\hline Діапазон ПВК, нмІ & група $1, \mathrm{n}=20$ & група 2, $\mathrm{n}=18$ & група $3, \mathrm{n}=20$ & група 4, $\mathrm{n}=14$ \\
\hline $6-7$ & - & $55,6 \%$ & $45 \%$ & $21,44 \%$ \\
\hline $8-9$ & $40 \%$ & $22,2 \%$ & $30 \%$ & $42,86 \%$ \\
\hline$\geq 10$ & $60 \%$ & $22,3 \%$ & $25 \%$ & $35,7 \%$ \\
\hline
\end{tabular}

У двох тварин зі значеннями ПВК $13-14$ Ч $10^{-4} \mathrm{HмI}$ діагностували гостру ниркову недостатність, за якої у зв'язку 3 коротким терміном розвитку хвороби площа волосяної кутикули залишилась на рівні показників у здорових собак.

У котів 3 групи 3 , в яких встановили печінково-нирковий синдром, ПВК 6-7Ч10-4 нмІ зустрічається у $45 \%, 8-9410^{4} \mathrm{HмI}$ - у $30 \%$ хворих котів, а показник більше за $10410^{-4} \mathrm{Hм}^{2}$ - тільки у $10 \%$. Отже, за результатами визначення ПВК ниркова патологія у 88,8 \% та печінково-нирковий синдром у 90,0 \% свійських котів діагностували, коли результати визначення ПВК були в межах від $6 Ч 10^{-4}$ до $10 Ч 10^{-4} \mathrm{нм}^{2}$. За ПВК 15 Ч10-4нм ${ }^{2}$ у тварин стовідсотково не виявляли захворювань нирок. За печінково-ниркового синдрому верхній ліміт ПВК не перевищував $12410^{-4} \mathrm{HмI}$, чим свідчив про більш тяжкий перебіг хвороби, ніж за монопатології нирок, що негативно впливає на стан волосяного покрову (табл. 2).

У котів з групи 4 за нирково-печінкового синдрому ПВК у діапазоні $6-7$ - $10^{-4} \mathrm{HмI}$ зустрічається рідше на $23,56 \%$, ніж у групі 3 , тобто у тварин із печінково-нирковим синдромом. Проте в більшої кількості випадків (на 12,86\%) за первинного ураження нирок реєструється ПВК $8-9410^{-4} \mathrm{HMI}$.
У цій групі ПВК більша, ніж $10410^{-4} \mathrm{HмI,} \mathrm{встанов-}$ лена у 14,3 \% тварин. За обох синдромів, тобто у групах 3 і 4, на $100 \%$ відсутні тварини з ПВК 13 Ч $10^{-4}$ нмІ і вище.

Отже, шляхом порівняння верхньої межі ПВК у тварин груп 1-4 можна бачити різницю у стані шерстного покрову в нормі та за різних хвороб і синдромів: у клінічно здорових свійських котів це $17410^{-4}$ нмI (5,0 \% випадків), за патології нирок - 14 Ч $10^{-4}$ нмI (5,6 \% випадків), за печінковониркового та нирково-печінкового синдромів $12410^{-4}$ нм (5,0 і 7,15 \% випадків відповідно). Таким чином, нижче значення ПВК відповідає тяжчому перебігу захворювання.

Об'єднавши тварин 3 обома варіантами синдромів 3 метою збільшення вибірки $(\mathrm{n}=34)$, ми ставили за завдання оцінити можливість диференціювання їх від здорових котів і тварин 3 монопатологією нирок за значеннями ПВК. Виявилося, що в котів 3 групи 5, тобто за обох синдромів, значення ПВК знаходилось у межах 6-7Ч $10^{-4} \mathrm{HMI}$ у $35,27 \%$ випадків, за патології нирок - у 55,6 \% і стовідсотково було відсутне у клінічно-здорових свійських котів. ПВК більше 10 Ч $10^{-4}$ нмІ за обох синдромів та захворювання нирок зустрічалось у 11,78 та $11,20 \%$ тварин відповідно і у $35 \%$ котів 


\section{ВЕТЕРИНАРНА МЕДИЦИНА}

без клінічних ознак будь-якої патології.

За даними таблиці 2 , діапазон значень ПВК $8410^{-4}$ нмI і більше спостерігався у $100 \%$ здорових свійських котів, а 6-7Ч10 ній і $є$ типовим для більшості котів із захворюваннями нирок (55,6 \%) та обох варіантів поліорганної патології. Найбільша кількість тварин за печінковониркової патології 3 даним діапазоном ПВК складає $45 \%$, за нирково-печінкової майже у 2 рази рідше $21,44 \%$. Отже, найсильніший ступінь токсичного впливу на стан волосяного покрову в котів, який призводить до зниження ПВК до найменших значень, спостерігається за монопатології нирок, а саме за хронічної ниркової недостатності. Діапазон ПВК 8-9Ч $10^{-4}$ нмI найчастіше спостерігається в котів із нирково-печінковою патологією - у 42,86 \% випадків, у той час як за печінково-ниркової - у 30 \% тварин і менш за все (у 22,2 \% тварин) - за монопатології нирок. Таким чином, виникає припущення, що за нирково-печінкової недостатності вплив ендотоксинів на розмір ПВК у котів проявляється дещо в меншій мірі, ніж за печінково-ниркової. За ПВК $10410^{4}$ нмI і вище найрідше спостерігаються випадки монопатології нирок (22,3 \%), далі - печінковониркові патології $(25,0$ \%) і у 35,7 \% тварин може розвинутись нирково-печінкова патологія.

Узагальнюючи результати досліджень, констатуємо, що показники ПВК 6 і 7Ч10-4 нмІ не зустрічаються у здорових свійських котів, а поєднана печінково-ниркова та нирково-печінкова патології не супроводжуються значеннями ПВК $13410^{-4} \mathrm{HмI}$ і вище. Монопатологія нирок у котів у залежності від форми і стадії захворювання супроводжується коливаннями ПВК у діапазоні від 6 до 14Ч10 ${ }^{-4}$ нмI і їі ніколи не супроводжують значення ПВК 15 Ч $10^{-4}$ нмІ і вище.

Приклади клінічних випадків

Приклад №1. Кіт-самець, вік - 6 років, безпородний; тривалий час спостерігаються алопеції в області тазу, $\mathrm{T} 37,9^{\circ} \mathrm{C}$, стан пригнічений, апетит знижений. Під час пальпації тварина напружена, сечовий міхур наповнений. В анамнезі ниркова недостатність. За результатами аналізів у сироватці крові виявлено підвищення вмісту креатиніну у 7,5 рази, сечовини - у 10 рази. Рівень загального білка був у межах норми. За результатами досліджень у тварини діагностовано хронічну ниркову недостатність у стадії загострення. Діагноз підтверджується низьким значенням ПВК $7 \times 10^{4}$ нмI (рис. 1).

Приклад № 2. Кіт-самець, 1,3 роки, Т $38,0{ }^{\circ} \mathrm{C}$, стан пригнічений, апетит знижений, в анамнезі отруєння. У сироватці крові вміст загального білка вище за норму у 1,3 рази, активність трансаміназ збільшена: АлАТ у 3.7, АсАТ майже у 2,0 рази. Рівень сечовини підвищений у 2,0 ра- зи, креатиніну - в 1,3 рази. За результатами дослідження на тлі отруєння розвинувся нирковопечінковий синдром. Показник ПВК у даної тварини $10 \times 10^{4}$ нмI (рис. 2).

Приклад 3. Кіт-самець, 3 роки, безпородний. Скарг від власників немає. Під час клінічних досліджень відхилень від норми не встановлено. Показники сироватки крові знаходились у діапазоні норми. Показник ПВК у даної тварини $14 \times 10^{4}$ нмI (рис. 3 ).

Висновки. У $40 \%$ клінічно здорових свійських котів розміри площі волосяної кутикули (ПВК) ста-

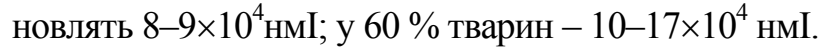
Такий значний розкид показників зумовлений різним віком тварин і впливом породного фактору, проте у $100 \%$ клінічно здорових котів відсутні значення ПВК $6-7 \times 10^{4}$ нмІ. Чим більше ПВК $\left(13 \times 10^{4}\right.$ нмI і вище), тим менше вірогідність, що у тварини $є$ прихована або початкова форма захворювання нирок і стовідсотково відсутня поліорганна печінково-ниркова та нирково-печінкова патології.

Монопатологія нирок у свійських котів у залежності від форми і стадії захворювання супроводжується коливаннями ПВК. За гострої ниркової недостатності показники переважно знаходяться в діапазоні значень $13-14 \times 10^{4} \mathrm{HмI}$, тобто можуть не відрізнятись від показників норми; за хронічної ниркової недостатності - у діапазоні 6-10×104 нмI. Взагалі, за захворювань нирок не зустрічаються значення ПВК, вищі за 15 нмI.

За поліорганної патології у формі печінковониркового та нирково-печінкового синдромів ПВК у свійських котів становить $6-12 \times 10^{4}$ нмI і стовідсотково не зустрічається за межами цього діапазону. Диференціювати обидва синдроми на цей час тільки за розмірами ПВК важко, оскільки для цього необхідна більша кількість хворих тварин, 3 урахуванням їх вікових та породних особливостей. Проте в поєднанні з результатами біохімічних досліджень сироватки крові ця методика дозволяє діагностувати синдроми в залежності від первинної ланки патогенетичного ланцюга.

Методику визначення ПВК можна використовувати в комплексі з клінічними, інструментальними та лабораторними дослідженнями для диференціальної діагностики різних варіантів патології печінки й нирок; вивчати мало відомі ланки патогенезу внутрішніх незаразних хвороб свійських тварин; застосовувати під час диспансерного обстеження тварин даного виду; принцип її проведення можливо використовувати для вивчення стану здоров'я тварин інших видів у нормі та за патології. 


\section{ВЕТЕРИНАРНА МЕДИЦИНА}

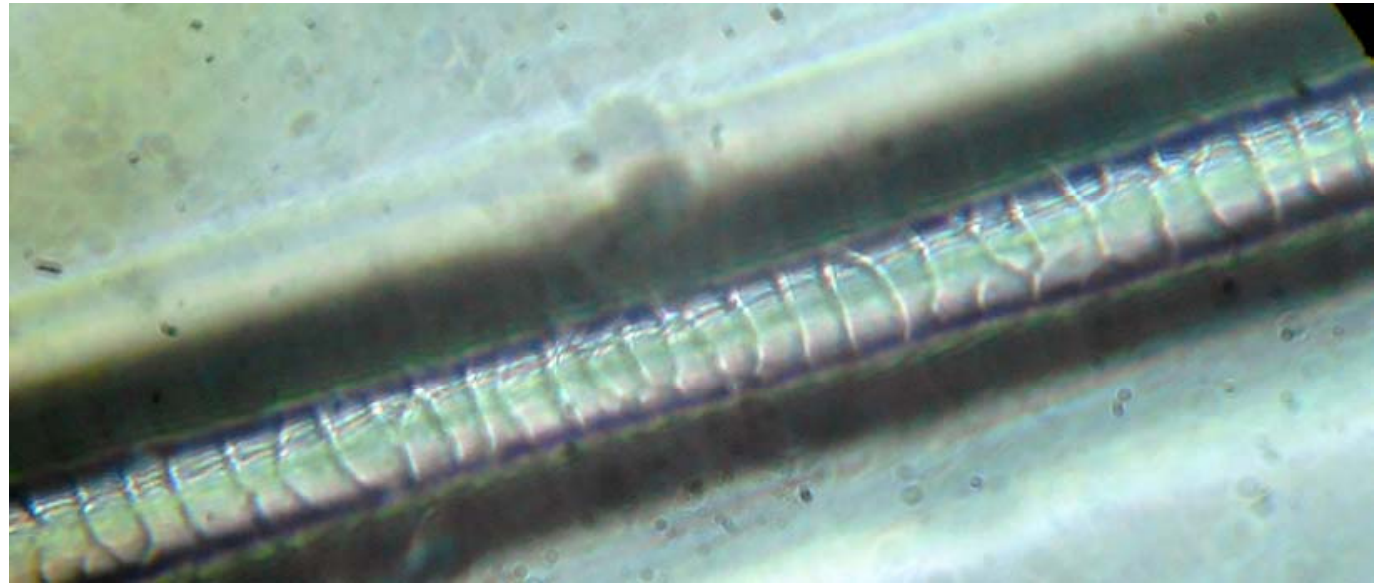

Рис. 1. Волосяна кутикула кота з діагнозом «хронічна ниркова недостатність» зі значенням ПВК $7 \times 10^{4} \mathrm{Hм}^{2}$

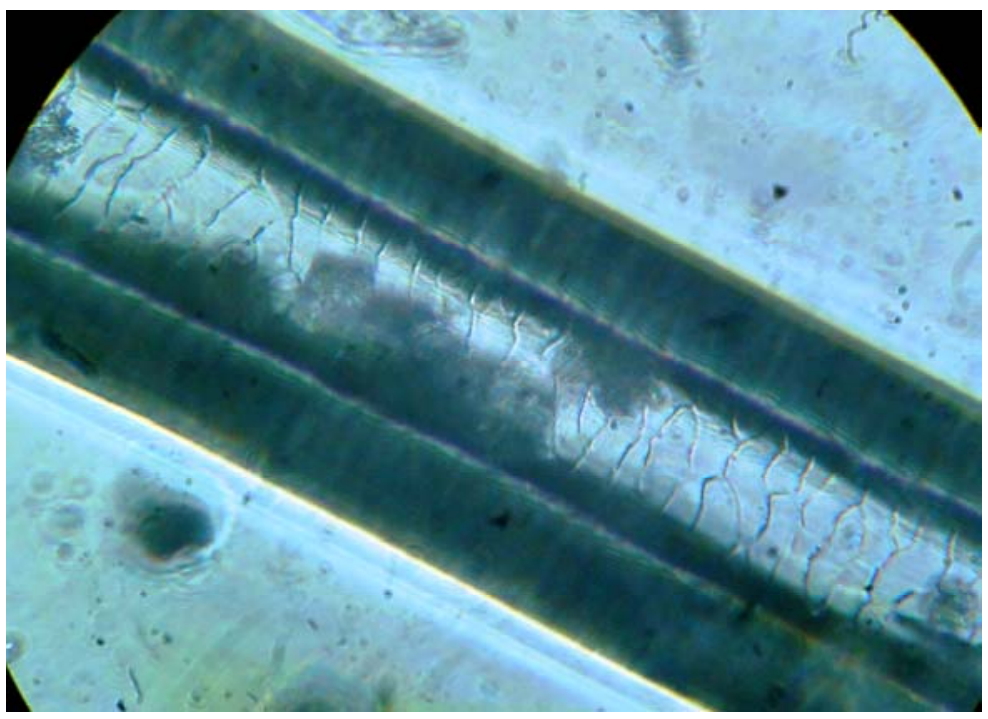

Рис. 2. Волосяна кутикула кота з діагнозом «нирково-печінковий синдром» зі значенням ПВК 10-10 н.м $^{2}$

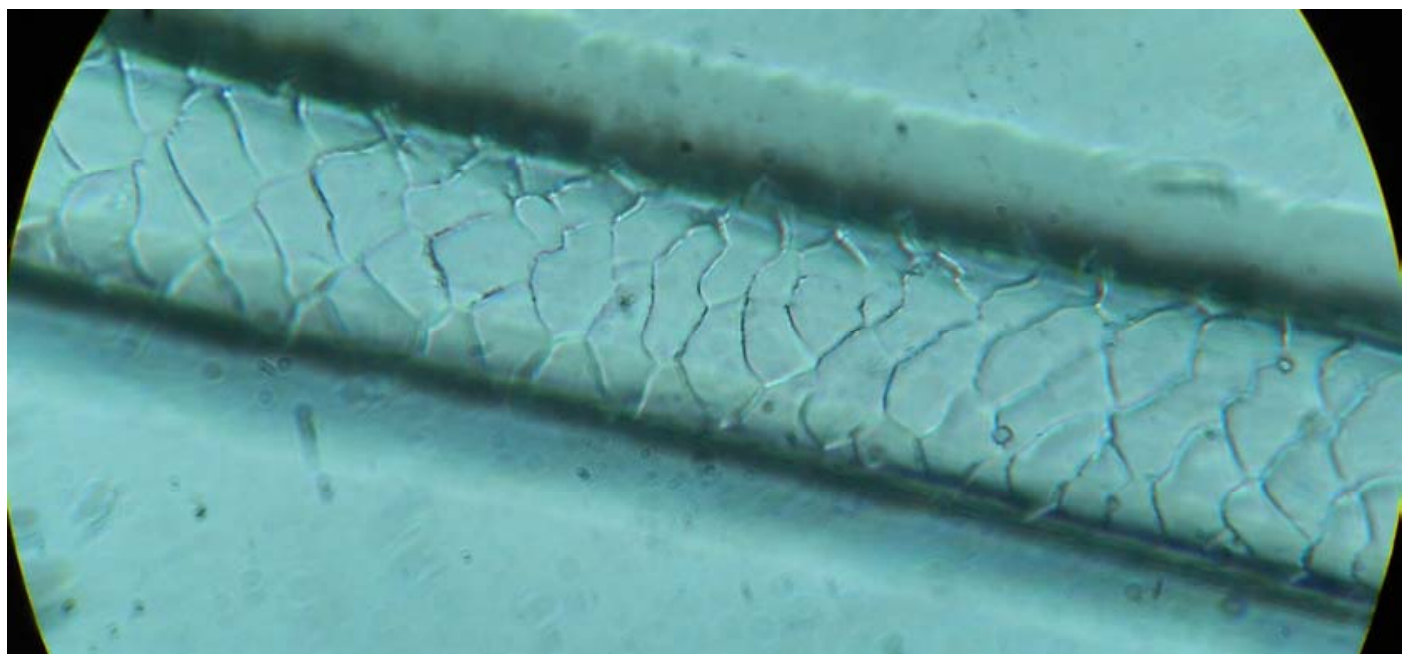

Рис. 3. Волосяна кутикула клінічно здорового кота зі значенням ПВК $14 \times 10^{4}$ нм$^{2}$ 


\section{БІБЛІОГРАФІЯ}

1. Болезни собак и кошек. Комплексная диагностика и терапия болезней собак и кошек: учеб. пособие / [Т. К. Донская Г. Г. Щербаков, Г. В. Полунин]; под ред. С. В. Старченкова. С.-Пб., 2006. -655 с.

2. Внутрішні хвороби тварин / [В. І. Левченко, П. Кондрахін, В.В. Влізло [та ін.]; за ред. В.І. Левченка. - Біла Церква, 2012. - Ч. 1. - 528 с.

3. Головаха B. I. Гепато-ренальний синдром у службових собак / В. І. Головаха, О. А. Дикий // Наукові досягнення в галузі ветеринарної медицини: Матеріали Міжнародної науковопрактичної конференції молодих вчених (1-2 квітня). - Харків, 1997. - С. 17-18.

4. Зимин П. В. Сравнительная морфология кожно-волосяного покрова у некоторых видов домашних и диких копытных животных: Дис. канд. вет. наук: 16.00.02. - Саратов, 2006. $123 \mathrm{c}$.

5. Івасишин Т. М. Волосся як об'єкт судовобіологічної експертиз: Дис. на здоб. канд. біол. наук: 03.00.11. - Київ, 2005. - 125 с.

6. Інформативність окремих показників для діагностики патології печінки і нирок у собак / А. Дикий, В. І. Головаха, В. П. Фасоля [та ін.] Вісник Білоцерківського державного аграрного іверситету. - Біла Церква, 2000. - Вип. 11. C. 32-37.

7. Кащь Г.Д. Морфология кожи и волос. Луганск : Знание, 2001. - 32 с.

8. Кацьь Г.Д., Коюда Л. И. Методы оценки защитных систем организма млекопитающих: Учебно-методическое пособие.- Луганск : Луганский нац. аграрный ун-т, 2003. - 96 с.

9. Кисин М. В. Судебно-биологическая экспертиза волос животных // Методики экспертного исследования. - М. : РФЦСЭ, 2001. - Вып. 2. $-175 \mathrm{c}$.

\section{ANNOTATION}

Tymoshenko O. P., Snopenko O. S. Change of areas of hair cuticle in sleep cats for nephropathy and polyorganic pathology.

89 males and females of domestic cats, aged 2.510.0 years, were examined. It was established that under different variants of nephropathy and for the development of hepatic and renal hepatic syndromes in domestic cats in the liver and kidneys there are significant structural changes that is reflected in the disturbances of metabolic processes determined by the results of clinical and microscopic and biochemical studies of blood serum, as well as changes
10. Локес П. І. Патологія печінки та органів сечової системи у свійських собак і котів (клініко-біохімічний статус, патогенез, діагностика, лікування): автореф. дис. на здобуття наук. ступеня доктора вет. наук: спец.16.00.01 «Діагностика і терапія тварин». - Київ, 2013. $44 \mathrm{c}$.

11. Кондрахин И. П. Методы ветеринарной клинической лабораторной диагностики - Справочник. - М. : Колос, 2004. - С. 520.

12. Морозенко Д. В. Інформативність клініколабораторних та інструментальних досліджень у діагностиці патології нирок у домашніх котів / Д. В. Морозенко, М. І. Карташов, А. М. Закревський // Вісник Білоцерківського державного аграрного університету: зб. наук. праць. - Біла Церква, 2006. - Вип. 40. - С. 138-146.

13. Тимошенко О. П., Папєта Г. А., Снопенко O. С., Периева Г. В. Порівняння клініко-гематологічних показників у собак і котів за поліморбідної патології / О.П.Тимошенко, Г. А. Папєта, О. С. Снопенко, Г. В. Перцева // Проблеми зооінженерії та ветеринарної медицини: Зб. Наук. праць Харківської державної зооветеринарної академії. - Харків. - РВВ ХДЗВА, 2016. - Вип. 33. - Ч. 2 «Ветеринарні науки». - С. 29-35.

14. Тимотенко О.П. Метаболический профиль сыворотки крови домашних кошек при полиморбидной патологии / О.П.Тимошенко, Г. А. Папєта, О. С. Снопенко, Г. В. Перцева, Н. В. Пименов // ФГБОУ ВПО МГАВМиБ. - М., 2017. - Вып. 11. Н. В. - С. 65-69.

15. Фасоля В. П. Діагностика і лікування гепато-ренального синдрому у собак службових порід / В. П. Фасоля // Вісгик Білоцерківського державного аграрного університету: зб. наук. праць. - Біла Церква, 2008. - Вип. 51. - С. 102107.

in the area of hair cuticle (AHC) of the wool cover of cats. The study of the cuticle was carried out using negative impressions on a nitrocellulose lacquer, which was applied to the slide glass. Hair was removed from him after lacquering. The resulting imprint was analyzed under Carl Zeiss Jena microscope ( 4 400) and set the AHC in the root zone and in the thickest part of the rod, expressing the result in $\mathrm{nm}^{2}$. In $40 \%$ of clinically healthy cats, the size of the hair cuticle (AHC) is $8-9 \times 10^{4} \mathrm{~nm}^{2}$; in $60 \%$ of animals $-10-17 \times 10^{4} \mathrm{~nm}^{2}$. Such a significant spread of indicators is due to different age of animals and 


\section{ВЕТЕРИНАРНА МЕДИЦИНА}

the influence of the rock factor. It turned out that $100 \%$ of clinically healthy cats do not have the values of AHC $6-7 \times 10^{4} \mathrm{~nm}^{2}$. The higher the AHC $\left(13 \times 10^{4} \mathrm{~nm}^{2}\right.$ or higher), the less likely an animal is the shelter or the initial form of kidney disease, and there is not one-hundred percent polyorganic hepatic-renal or renal-hepatic pathology. For acute renal failure, AHC values are predominantly in the range of values $13-14 \times 10^{4} \mathrm{~nm}^{2}$, that is, they do not differ from the norm. For chronic renal insufficiency, the value of AHC is $6-10 \times 10^{4} \mathrm{~nm}^{2}$. In general, for kidney diseases, there are no AHC higher than $15 \mathrm{~nm}^{2}$. In polyorganic pathology in the form of hepatic-renal and renal-hepatic AHC syndromes in domestic cats, they are $6-12 \times 10^{4} \mathrm{~nm}^{2}$ and are not completely found outside the given range. In combination with the results of clinical and biochemical studies of blood serum, this technique allows differentiating syndromes depending on the primary link of the pathogenetic chain. It can be used for the dispensary examination of domestic cats, as well as for the study of the animals' health of other species in normal and in pathology.

Key words: cats, nephropathy, polyorganic pathology, area of hair cuticle, diagnosis. 